Emir. J. Food Agric. 2009. 21 (2): 01-17

http://cfa.uaeu.ac.ae/ejfa.shtml

\title{
The effect of arbuscular mycorrhizal root colonization on growth and nutrient uptake of two different cowpea (Vigna unguiculata [L.] Walp.) genotypes exposed to drought stress
}

\begin{abstract}
E. Neumann ${ }^{1,2}$ and E. George ${ }^{1,3}$
${ }^{1}$ Leibniz Institute of Vegetable and Ornamental Crops (IGZ), 14979 Grossbeeren, Germany; ${ }^{2}$ Institute of Plant Nutrition (330), Hohenheim University, 70593 Stuttgart, Germany; ${ }^{3}$ Department of Crop Sciences, Humboldt University, 10099 Berlin, Germany

Abstract: In the present investigation, the effect of arbuscular mycorrhiza (AM) fungal root colonization on nutrient uptake, growth and soil water depletion of cowpea plants exposed to a drought stress period was studied in a greenhouse experiment. Arbuscular mycorrhizal and nonAM plants of an old, local variety from Brazil 'Carioca', and of the breeding improved cultivar 'Epace-10' were exposed to 24 days of drought, with or without a subsequent period of water resupply. Control plants remained well watered throughout the growth period. The AM symbiosis greatly enhanced nutrient uptake of drought stressed plants. However, water uptake, growth and net photosynthesis were unaffected by AM root colonization during drought stress. Recovery after water resupply was much faster when plants were inoculated with AM, probably due to an improved plant nutritional status. The cultivar Epace-10 was much more dependent on the AM symbiosis for growth and nutrient uptake compared with Carioca in all irrigation treatments. Only when roots were AM colonized, Epace-10 plants were able to recover from drought stress after water resupply. Our study suggests that the AM symbiosis constitutes an important strategy by which leguminous plants overcome periods of drought. Under conditions of low soil water and P availability, the presence of AM fungal propagules in the field soil appears to be a prerequisite for successful cultivation of cowpea, particularly with respect to the breeding improved cultivar Epace-10.
\end{abstract}

Key words: Arbuscular mycorrhiza, cowpea genotypes, drought stress, nutrient uptake, water uptake.

Abbreviations: AM - Arbuscular mycorrhiza; DW - Dry weight; WUE - Water use efficiency; -M -Plants grown in absence of AM fungi; $+\mathrm{M}$ - Plants grown in presence of AM fungi; WW - Plants well watered throughout the growth period; DS - Plants exposed to a period of drought stress; WR - Plants exposed to a period of drought stress with subsequent water resupply.

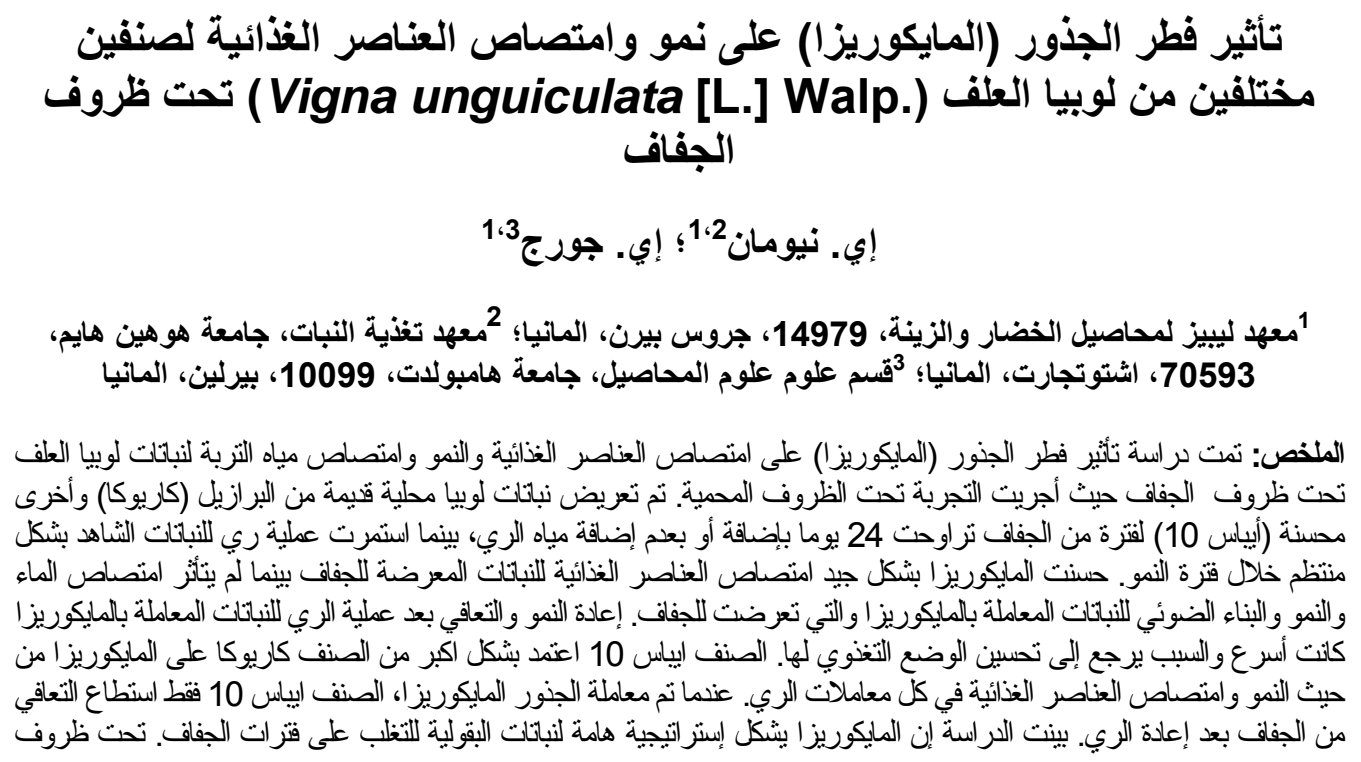




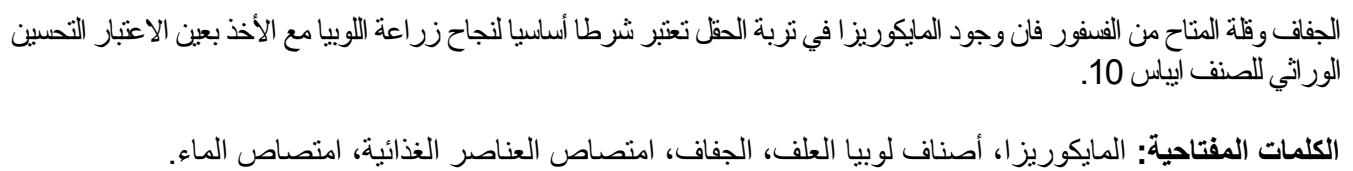

\section{Introduction}

Cowpea is an economically important staple food crop in many semiarid regions of the tropics and subtropics, grown mainly by subsistence farmers under low input of agrochemicals or irrigation water (Timko and Singh, 2008). With a protein content of above $20 \%$, cowpea beans and leaves constitute a nutritionally valuable component of the diet of the rural population in many parts of sub-Sahelian Africa and South America (Silva-Barbeau et al., 1998; Kabas et al., 2007). Due to its ability to produce rewarding yields even under adverse soil conditions such as Al toxicity, poor nutrient availability or drought (Kolawole et al., 2000; Labuschagne et al., 2008), cowpea is frequently cultivated on land only marginally suitable for crop production.

Drought limits plant growth on a large proportion of the world's agricultural land. Under low levels of soil moisture, not only water but also nutrient availability may be severely decreased when compared with well watered conditions (Gahoonia et al., 1994). Plants adapted to arid and semiarid ecosystems have evolved a broad variety of strategies to withstand periods of drought stress. These include high internal water and nutrient use efficiencies as well as facilitation of water and nutrient uptake from dry soil (Bray, 1997). To manage and make use of these plant adaptations in agricultural plant production may be a way to secure yields and to reduce input of irrigation water and fertilizer in arid and semiarid agroecosystems (Davies et al., 2002; Passioura, 2007).

The symbiosis of plant roots with AM fungi is known to be one of the most ancient and widespread plant strategies to enhance nutrient acquisition and to cope with environmental stress (Brachmann and Parniske, 2006). The intra-radical mycelium of these soil fungi proliferates in the root cortex of the host plant. Extraradical AM hyphae spread in the soil around the root and provide the surface area by which the AM fungus absorbs nutritional elements such as phosphorus $(\mathrm{P})$, nitrogen $(\mathrm{N})$, zinc $(\mathrm{Zn})$ or copper $(\mathrm{Cu})$ for transport and transfer to the host plant (George, 2000; Smith and Read, 2008).

Roots of plants native to arid and semiarid ecosystems often show high levels of AM fungal root colonization, indicating a considerable relevance of the symbiosis for plant performance under water limitation (Chaudhry et al., 2005; Shi et al., 2006; Tchabi et al., 2008). Recent studies have indeed shown that the extra-radical AM mycelium is able to transfer water to its host plant under conditions of low soil moisture (Marulanda et al., 2003; Khalvati et al., 2005). Whether amounts of water transported via the AM hyphae network are large enough to significantly contribute to plant performance under drought is discussed controversially (George et al., 1992; Koide, 1993). Better maintenance of cell turgor as well as higher net photosynthesis, water use efficiency (WUE) and growth have frequently been observed in AM colonized plants compared with non-AM controls exposed to drought (Augé, 2004). These effects have sometimes been attributed to an improved $\mathrm{P}$ or $\mathrm{N}$ nutritional status of AM plants (AlKaraki and Clark, 1998; Neumann et al., 2009), but may also occur irrespectively of AM contribution to plant nutrient 
uptake (Porcel and Ruiz-Lozano, 2004; Pinior et al., 2005).

More than $80 \%$ of all studies conducted on plant/AM interactions under drought showed improved performance of AM colonized compared with non-AM treatments (Augé, 2001). However, in many previous studies plants were exposed to relatively short (7-14d) periods of drought before harvest (e.g. Schellenbaum et al., 1998; Porcel and Ruiz-Lozano, 2004; Augé et al., 2007). Under field conditions, drought periods may prevail longer and lead to a continuous decrease in the soil moisture level over time. Drought periods are also often temporarily limited, and the ability of the plant to rapidly recover after water resupply may be important in terms of yield. The aim of the present study was therefore to compare the performance of AM and non-AM cowpea plants exposed to a longer period of drought, with or without subsequent resupply of water.

Breeding improved plant cultivars have often been shown to exhibit higher growth and nutrient uptake compared with old varieties under optimum growth conditions as well as under environmental stress such as low nutrient supply or drought (Abeledo et al., 2003; Guarda et al., 2004). Previous investigations have shown that different cultivars of the same plant species can differ considerably in the extent by which they benefit from the AM symbiosis under well watered conditions (Eason et al., 2001; Linderman and Davis, 2004), but only few studies compared improved and old crop varieties (Hetrick et al., 1992; Graham et al., 1997). Almost nothing is known about whether improved cultivars and old varieties differ in the extent by which they depend on the AM symbiosis for growth and nutrient uptake under dry soil conditions. Therefore we compared plants of an old, local cowpea variety from Píaui, Brazil with the breeding improved cultivar 'Epace-10' in our study.

\section{Materials and Method}

Seeds of the cowpea (Vigna unguiculata [L.] Walp. ssp. unguiculata) cultivar 'Epace-10' were obtained from the seed bank of the Centro de Ciências Agrárias, Universidade Federal do Ceará, Fortaleza, Brazil. Epace-10 is a breedingimproved cultivar with a semi-vining habitus. Seeds of an older, vining cowpea variety with light brown testa, locally termed 'Carioca', were obtained from farmers in Pìaui, Brazil. The seeds were surface sterilized in $5 \% \quad \mathrm{H}_{2} \mathrm{O}_{2}$ for five minutes and germinated on moist filter paper for four days. The seedlings were transferred to round plastic planting pots with a diameter of $10 \mathrm{~cm}$ (VTA 10, Teku, Germany) filled with $380 \mathrm{~g}$ dry soil at a bulk density of $1.3 \mathrm{~g} \mathrm{~cm}^{-3}$. The soil had been dry heated two times for $24 \mathrm{~h}$ at $85^{\circ} \mathrm{C}$ with an interval of $48 \mathrm{~h}$ at room temperature to eliminate AM fungal propagules. Prior to heating, the sieved (2 $\mathrm{mm})$ soil contained $\left(\mathrm{mg} \mathrm{kg}^{-1}\right) 5.2$ and 3.4 $\mathrm{CaCl}_{2}(0.0125 \mathrm{M})$ - extractable $\mathrm{NH}_{4}{ }^{+}$and $\mathrm{NO}_{3}{ }^{-}$, respectively, 4.4 acetate lactateextractable (CAL; Schüller 1969) P, 58 CAL-extractable $\mathrm{K}$, and $1.93(\mathrm{Fe}), 1.75$ $(\mathrm{Mn}), 0.10(\mathrm{Zn})$ and $0.16(\mathrm{Cu})$ DTPAextractable micronutrients. The soil had a $\mathrm{pH}\left(0.01 \mathrm{M} \mathrm{CaCl}_{2}\right)$ of 7.3 and $0.2 \%$ organic matter. It was classified as loamy sand $(45.2 \%$ sand, $42.0 \%$ silt, $12.8 \%$ clay). The soil was fertilized with $200 \mathrm{mg}$ $\mathrm{K}\left(\mathrm{K}_{2} \mathrm{SO}_{4}\right), 200 \mathrm{mg} \mathrm{N}\left(\mathrm{NH}_{4} \mathrm{NO}_{3}\right), 100 \mathrm{mg}$ $\mathrm{Mg}\left(\mathrm{MgSO}_{4}\right), 50 \mathrm{mg} \mathrm{P}\left(\mathrm{Ca}\left(\mathrm{H}_{2} \mathrm{PO}_{4}\right) 2\right.$. $\left.\mathrm{H}_{2} \mathrm{O}\right), 10 \mathrm{mg} \mathrm{Zn}\left(\mathrm{ZnSO}_{4} \cdot \mathrm{H}_{2} \mathrm{O}\right), 10 \mathrm{mg} \mathrm{Cu}$ $\left(\mathrm{CuSO}_{4}\right)$, and $10 \mathrm{mg} \mathrm{Fe}\left(\mathrm{FeNH}_{4}\right.$-citrate) per $\mathrm{kg}$ dry soil.

To establish AM $(+\mathrm{M})$ plants, a 2:1 $(w / w)$ mixture of inoculum of the AM fungi Glomus intraradices (BEG 110) and Glomus mosseae (BEG 107) was homogeneously mixed with the soil. The Inoculum, representing $6 \% \mathrm{w} / \mathrm{w}$ of the growth substrate, consisted of AM colonized root pieces and adhering airdried soil containing extraradical AM mycelium with spores. It had been 
propagated in open pot culture on onion and potato plants using the same soil as described above. The inoculum for the non-AM control treatments (-M) was filtered with deionised water $(70 \mathrm{ml}$ per $50 \mathrm{~g}$ dry inoculum through Blue Ribbon filter paper, Schleicher and Schüll, Germany) before being autoclaved. The filtrate was added to the soil of the -M treatments to encourage a microflora similar as in the $+\mathrm{M}$ treatments.

The plants were grown for six weeks before they were transplanted with their complete root bale into larger square planting pots $(1.7 \mathrm{~L}$, Goettinger, Germany) filled with $1500 \mathrm{~g} / 1.3 \mathrm{~g} \mathrm{~cm}^{-3}$ of the same dry soil as described above. The soil for the larger planting pots was fertilized in the same way as the soil used for precultivation, but did not receive AM inoculum.

During precultivation and the first 36 days after transplanting, water loss from the planting pots was estimated gravimetrically at least once per day, and replaced with deionised water to maintain an average soil water content of approximately $22 \% \quad w / w$. Thereafter, water supply was either maintained at this level (well watered treatments, WW), or decreased to impose drought stress (DS). At the beginning of the drought stress period, both plant genotypes were about to start flowering. Throughout a drought stress period of 24 days, DS plants were temporarily wilted but not irreversibly damaged. The soil water content in the DS pots was assessed by time domain reflectometry (TDR; TEKTRONIX, 1502 C/Tektronix Oregon, United States) according to Roth et al. (1990). A $12 \mathrm{~cm}$ head with three pins was installed in each root compartment. The soil water content was measured at least once per day before plants were watered, and the soil water content after watering was calculated from the amounts of water added to the pot. The mean soil water content was estimated by averaging these two values, assuming that the depletion of water from the soil between the irrigation intervals was approximately linear. At the end of the drought stress period, DS plants were either harvested or water was resupplied (WR) to the soil and maintained at the same level as in the WW treatments for another 18 days before harvest. Four replicates were prepared of each irrigation and AM inoculation treatment.

The experiment was conducted in a glasshouse at the Hohenheim University in Stuttgart, Germany $\left(48^{\circ} 25^{`} \mathrm{~N}, 9^{\circ} 11^{`} \mathrm{E}\right)$ under ambient light supply from July to October. Leaves lost over the growth period were collected for each plant and dried at $65^{\circ} \mathrm{C}$ in a drying oven before their dry weight (DW) was estimated.

One week after initiation of drought stress and one week after water resupply, net photosynthesis, leaf water conductivity and leaf transpiration were measured between two and four hours after sunrise over an area of $5 \mathrm{~cm}^{2}$ on the second youngest fully expanded leaf. The photosynthesis measuring system used (HCM 1000, Walz, Germany) employed infrared gas analysis to determine concentrations of $\mathrm{CO}_{2}$ and $\mathrm{H}_{2} \mathrm{O}$ according to Auble and Meyers (1992). The temperature in the measuring cuvette was $26{ }^{\circ} \mathrm{C}$ and the leaf surface was irradiated with $800 \mu \mathrm{mol}$ photons $\mathrm{m}^{2} \mathrm{~s}^{-1}$.

At time of harvest, the roots were washed from the soil and a representative sample of $0.2 \mathrm{~g}$ fresh weight was taken from each plant root system. Samples of plants of the same genotype and treatment were pooled before the AM fungal colonized root length was assessed by a modified intersection method (Tennant, 1975; Kormanik and Mc Graw, 1982). Intraradical fungal structures were stained with trypan blue in lactic acid (Koske and Gemma 1989). Between 300 and 350 intersections were counted per sample.

The plant material was dried at $65^{\circ} \mathrm{C}$ in a drying oven. After their DW was estimated, shoots, roots, and leaves lost 
over the growth period were analysed for their $\mathrm{P}, \mathrm{N}, \mathrm{K}, \mathrm{Cu}$ and $\mathrm{Zn}$ concentration separately. Samples of $200 \mathrm{mg}$ of ground plant material were dry ashed at $500{ }^{\circ} \mathrm{C}$, oxidised with $5 \mathrm{ml}$ of $1: 3$ diluted $\mathrm{HNO}_{3}$ and taken up into $25 \mathrm{ml}$ of 1:30 diluted $\mathrm{HCl}$. Phosphorus concentrations in the samples were analysed colorimetrically with a spectrophotometer (U 3300, Hitachi, Japan) at $436 \mathrm{~nm}$ wavelength after staining with ammonium - molybdate - vanadate solution (Gericke and Kurmies 1952). Potassium concentrations were quantified by a flame photometer (ELEX 6361, Eppendorf, Germany). Concentrations of $\mathrm{Cu}$ and $\mathrm{Zn}$ were measured by atomic absorption spectrometry (AAS; ATI Unicam 939/ Solaar, Thermo Electron, United States). An autoanalyser (Elementar Vario MAX CN/ Elementar Analysesysteme, Germany) was used to determine $\mathrm{N}$ concentrations in the plant material. Ground samples of $500 \mathrm{mg}$ were combusted at $1125^{\circ} \mathrm{C}$, and release of gaseous $\mathrm{N}$ was quantified by gas chromatography as described by Thieme (1964).

Statistics were calculated using the SigmaStat 2.03 Programme. Due to the earlier harvest of the DS treatment, data obtained for these plants after harvest could not be directly compared with corresponding values for WW and WR plants. The Three Way Analysis of Variance (ANOVA) performed on data obtained after plant harvest thus excluded values of DS plants.

\section{Results}

\section{Soil water content and evapo- transpiration throughout the growth period}

Throughout the drought stress period the soil water content in the DS pots gradually decreased from approximately $15 \%$ to less than $9 \%$ in both cowpea genotypes (Figure1). The soil water content in DS treatments was not different depending on whether plants were AM inoculated or not. The extent by which $+\mathrm{M}$ and $-\mathrm{M}$ plants of the DS treatment depleted the soil of water between the irrigation intervals did not differ significantly (t-test, $\mathrm{P}<0.05$; data not shown) throughout the drought stress period.

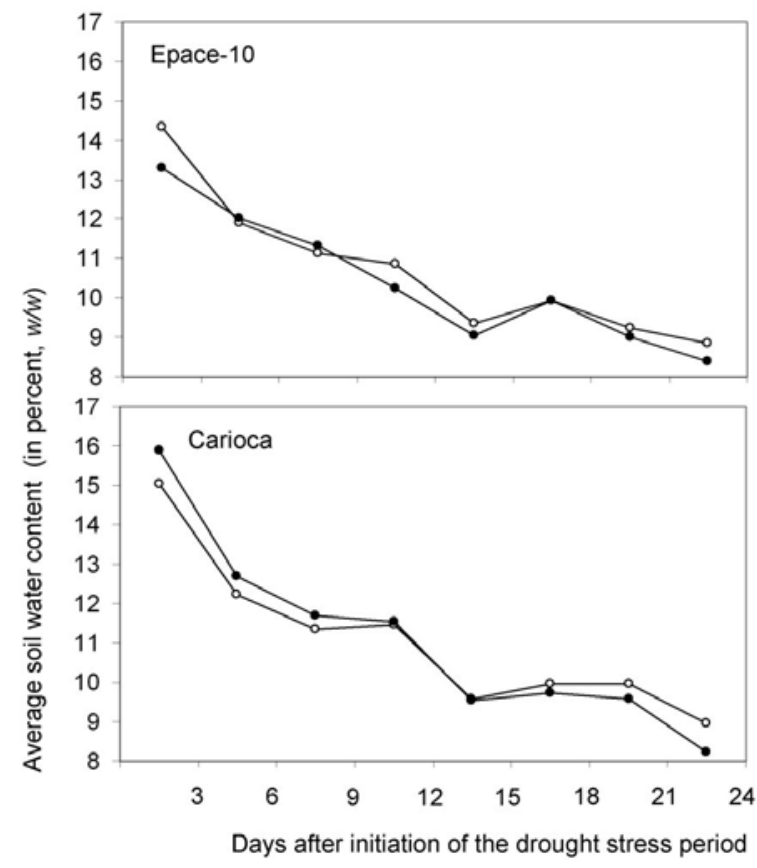

Figure 1. The average soil water content in drought stressed treatments throughout the drought stress period in percent $(w / w)$.

Shown are the mean values averaged over three days for nonmycorrhizal (open circles) and mycorrhizal (closed circles) treatments.

Values for nonmycorrhizal plants did not significantly differ from those of corresponding mycorrhizal treatments (t-test; $\mathrm{P}<0.05)$.

Arbuscular mycorrhiza effects on evapotranspiration generally appeared to be larger for Epace-10 compared with Carioca (Figure 2). During the drought stress period $+\mathrm{M}$ plants of the genotype Epace-10 showed a higher evapotranspiration compared with the corresponding - $\mathrm{M}$ treatment when they remained WW. Continuously well watered Carioca plants showed a higher daily evapotranspiration in response to AM inoculation only during the last three weeks before harvest. 
When exposed to dry soil, plants of both genotypes did not differ in their evapotranspiration depending on whether they were AM inoculated or not. However, when DS plants were resupplied with water, daily evapotranspiration of mycorrhizal WR plants far exceeded that of corresponding -M treatments until the time of harvest. The relative difference in evapotranspiration between $+\mathrm{M}$ and $-\mathrm{M}$ plants was much larger in WR compared with WW plants in both cowpea genotypes.

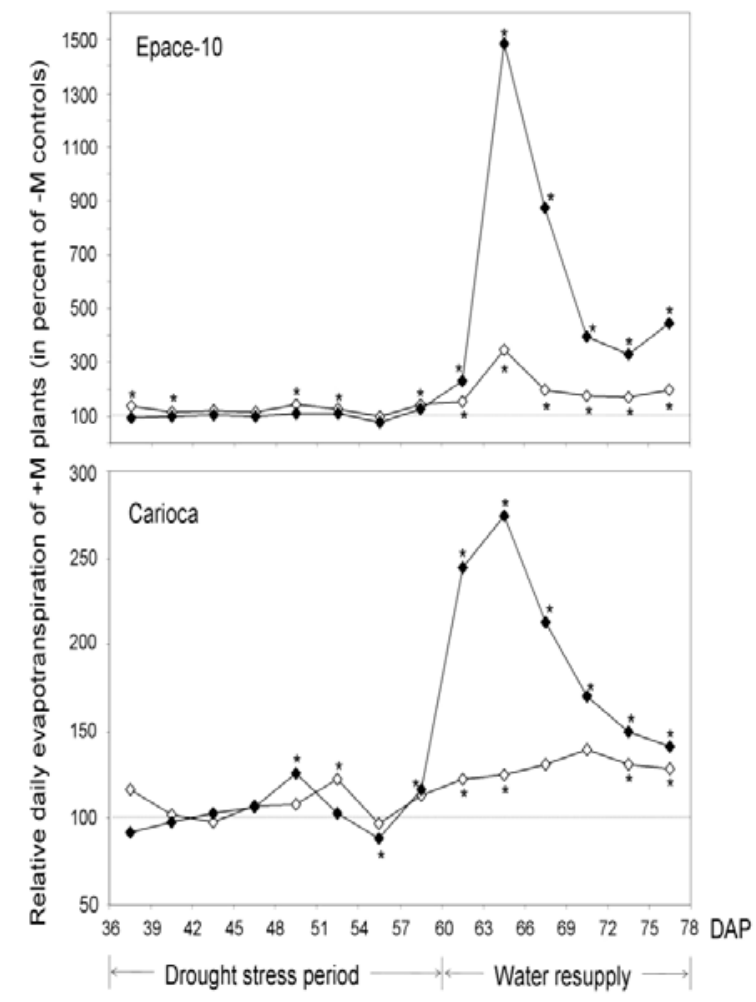

Figure 2. The daily evapotranspiration of mycorrhizal $(+M)$ plants in relation to nonmycorrhizal controls (-M) in percent $(-\mathrm{M}=100 \%)$ during the drought stress period and the period of water resupply. Shown are the mean values averaged over three days for the continuously well watered plants (open squares) and the treatments exposed to a drought stress period with subsequent resupply of water (closed squares). Mean values followed by a star indicate a significant difference $(\mathrm{P}<0.05)$ in average daily evapotranspiration between corresponding $+\mathrm{M}$ and $-\mathrm{M}$ treatments. $\mathrm{DAP}=$ Days after transplanting

\section{Photosynthetic activity during drought stress and after water resupply}

One week after the beginning of the drought stress period, DS plants showed a slight decrease in net photosynthesis, leaf conductivity and leaf transpiration compared with the WW controls (Table 1). In both genotypes WW as well as DS plants had a higher net photosynthesis when they were $-M$ instead of $+M$.

One week after water resupply net photosynthesis, leaf water conductivity and transpiration did not differ between $+\mathrm{M}$ and $-\mathrm{M}$ plants of the WW treatment. The mycorrhizal WR plants, however, showed higher values compared with the corresponding $-\mathrm{M}$ treatments. This effect appeared to be more pronounced in Epace-10 compared with Carioca.

\section{Plant dry weight, shoot/root-ratio and water use efficiency}

Plants of the local variety Carioca generally had a higher biomass and a lower shoot/root-ratio compared with Epace-10 (Table 2). The total DW of the DS plants was not different depending on whether they were AM or not. However, WW and WR plants showed a much higher DW when they were $+\mathrm{M}$ instead of $-\mathrm{M}$ in both genotypes. The shoot/rootratio was decreased in response to AM inoculation in WW and WR plants. In DS treatments, the shoot/root ratio was either unaffected (Epace-10) or increased (Carioca) in response to AM root colonization. Leaf loss was not different between $+\mathrm{M}$ and $-\mathrm{M}$ plants of the DS treatment. During the period of water resupply leaf loss from the WR plants was much higher when these were -M instead of $+\mathrm{M}$ in both genotypes. In the WW treatments leaf loss was also decreased by AM inoculation.

The two cowpea genotypes did not differ much in their WUE. There was also no big difference in WUE, depending on the irrigation treatment. While AM inoculation generally had a positive effect on WUE of Epace-10 
plants, there was no or even a negative effect of AM root colonization on WUE of Carioca.

\section{The extent of arbuscular mycorrhiza fungal root colonization at the time of harvest}

The AM fungal colonized root length in percent of the total root length appeared to be largely unaffected by the irrigation treatment in Carioca, where values for WW, DS and WR plants were $54 \%, 49 \%$ and $54 \%$, respectively. In Epace-10, values appeared to be slightly positively affected by drought stress. Values for WW, DS and WR plants were $45 \%, 67 \%$ and $59 \%$, respectively. No AM fungal root colonization was observed in the $-\mathrm{M}$ treatments. No nodules indicative of the formation of a symbiosis with Rhizobia were observed.

Total plant nutrient uptake and concentrations of nutritional elements in the shoot tissue

Total uptake of $\mathrm{P}, \mathrm{K}, \mathrm{N}$ and $\mathrm{Zn}$ was generally higher for Carioca compared with Epace-10 plants (Table 3). Arbuscular mycorrhizal root colonization strongly increased total plant $\mathrm{P}$ uptake compared corresponding -M plants in all irrigation treatments. During the period of water resupply, mycorrhizal WR plants almost doubled their $\mathrm{P}$ content compared with the plants harvested by the end of the drought stress period. The $\mathrm{P}$ uptake of nonmycorrhizal WR plants during the period of water resupply was only small.

In Epace-10, total $\mathrm{K}$ uptake was increased by AM root colonization in the WW and WR plants. Plants of this genotype also responded to AM inoculation with an increased uptake of $\mathrm{N}$ and $\mathrm{Zn}$ in all irrigation treatments. An effect of AM inoculation on the uptake of $\mathrm{K}$ and $\mathrm{N}$ was much smaller $(\mathrm{K})$ or absent $(\mathrm{N})$ in Carioca. This was mainly due to a higher nutrient uptake of -M plants of this variety compared with Epace-10. Uptake of $\mathrm{Zn}$ and $\mathrm{Cu}$ was generally lower for WR compared with WW plants. Inoculation with AM fungi increased total uptake of $\mathrm{Zn}$ and $\mathrm{Cu}$ in both genotypes.

Arbuscular mycorrhizal plants of both genotypes generally had more than two times higher shoot $\mathrm{P}$ concentrations compared with the corresponding -M treatments (Table 4). Differences in concentrations of other elements were much smaller between $-\mathrm{M}$ and $+\mathrm{M}$ plants. Arbuscular mycorrhizal Epace-10 plants of the DS treatment had significantly higher shoot concentrations of $\mathrm{N}$ and $\mathrm{Cu}$ compared with the corresponding -M treatment. Such an effect was not observed in Carioca plants.

\section{Discussion}

The results of our study cannot confirm earlier reports of deeper depletion of dry soil for water by $+\mathrm{M}$ compared with -M roots (Okon et al., 1996; Khalvati et al., 2005). However, it cannot be ruled out that $+\mathrm{M}$ and $-\mathrm{M}$ plants differed in their time-course of depleting water between the irrigation intervals in our study. Not only plant but also AM fungal genotypes appear to differ considerably in their particular adaptations to dry soil conditions (RuizLozano et al., 1995; Marulanda et al., 2007). Thus it is possible that the ability of the AM symbiosis to contribute to plant water uptake depends on the environmental conditions as well as the AM fungal strains and plant genotypes involved. 
Table 1. Net photosynthesis, leaf conductivity and transpiration one week after drought stress initiation and one week after water resupply.

\begin{tabular}{|c|c|c|c|c|c|c|c|c|c|c|c|}
\hline & \multicolumn{4}{|c|}{ Epace-10 } & \multirow{2}{*}{\multicolumn{4}{|c|}{ Carioca }} & \multirow{2}{*}{\multicolumn{3}{|c|}{$\begin{array}{l}\text { Three Way } \\
\text { ANOVA: }\end{array}$}} \\
\hline & \multicolumn{2}{|c|}{ WW } & \multicolumn{2}{|c|}{ DS / WR } & WW & & & & & & \\
\hline & $-\mathbf{M}$ & $+\mathbf{M}$ & $-\mathbf{M}$ & $+\mathbf{M}$ & $-\mathbf{M}$ & $+\mathbf{M}$ & $-\mathbf{M}$ & $+\mathbf{M}$ & G $\mathbf{W}$ & & I \\
\hline \multicolumn{12}{|l|}{ One week after drought stress } \\
\hline $\begin{array}{l}\text { initiation: } \\
\text { Net photosynthesis }\left(\mu \mathrm{M} \mathrm{CO}_{2} \mathrm{~m}^{-2} \mathrm{~s}^{-1}\right)\end{array}$ & $\begin{array}{l}9.55 \\
\pm 2.40\end{array}$ & $\begin{array}{l}6.64 \\
\pm 1.70\end{array}$ & $\begin{array}{l}8.02 \\
\pm 2.37\end{array}$ & $\begin{array}{l}5.30 \\
\pm 2.75\end{array}$ & $\begin{array}{l}9.41 \\
\pm 2.93\end{array}$ & $\begin{array}{l}5.99 \\
\pm 1.06\end{array}$ & $\begin{array}{l}5.22 \\
\pm 1.99\end{array}$ & $\begin{array}{l}5.03 \\
\pm 1.56\end{array}$ & & $\bullet$ & \\
\hline Leaf conductivity $\left(\mathrm{mM} \mathrm{H}_{2} \mathrm{O} \mathrm{m}^{-2}\right)$ & $\begin{array}{l}92.93 \\
\pm \\
39.21\end{array}$ & $\begin{array}{l}62.80 \\
\pm 23.51\end{array}$ & $\begin{array}{l}65.83 \\
\pm \\
29.43\end{array}$ & $\begin{array}{l}40.83 \\
\pm 28.46\end{array}$ & $\begin{array}{l}107.05 \\
\pm \\
54.64\end{array}$ & $\begin{array}{l}59.05 \\
\pm \\
17.11\end{array}$ & $\begin{array}{l}36.87 \\
\pm \\
14.08\end{array}$ & $\begin{array}{l}34.74 \\
\pm \\
13.78\end{array}$ & $\bullet$ & $\bullet$ & \\
\hline Leaf transpiration $\left(\mathrm{mM} \mathrm{H}_{2} \mathrm{O} \mathrm{m}^{-2} \mathrm{~s}^{-1}\right)$ & $\begin{array}{l}1.89 \\
\pm 0.62\end{array}$ & $\begin{array}{l}1.35 \\
\pm 0.40\end{array}$ & $\begin{array}{l}1.40 \\
\pm 0.47\end{array}$ & $\begin{array}{l}0.96 \\
\pm 0.58\end{array}$ & $\begin{array}{l}2.02 \\
\pm 0.76\end{array}$ & $\begin{array}{l}1.30 \\
\pm 0.22\end{array}$ & $\begin{array}{l}0.87 \\
\pm 0.33\end{array}$ & $\begin{array}{l}0.82 \\
\pm 0.34\end{array}$ & $\bullet$ & $\bullet$ & \\
\hline \multicolumn{12}{|l|}{ One week after water resupply: } \\
\hline Net photosynthesis $\left(\mu \mathrm{M} \mathrm{CO}_{2} \mathrm{~m}^{-2} \mathrm{~s}^{-1}\right)$ & $\begin{array}{l}5.94 \\
\pm 3.39\end{array}$ & $\begin{array}{l}5.15 \\
\pm 1.68\end{array}$ & $\begin{array}{l}2.16^{*} \\
\pm 1.06\end{array}$ & $\begin{array}{l}9.51 \\
\pm 1.50\end{array}$ & $\begin{array}{l}5.38 \\
\pm 1.67\end{array}$ & $\begin{array}{l}6.37 \\
\pm 2.22\end{array}$ & $\begin{array}{l}6.26 \\
\pm 1.82\end{array}$ & $\begin{array}{l}7.74 \\
\pm 2.68\end{array}$ & & & $\begin{array}{l}\mathrm{M} x \mathrm{~W} \\
\mathrm{C} x \mathrm{~W} x \mathrm{M}\end{array}$ \\
\hline Leaf conductivity ( $\mathrm{mM} \mathrm{H}_{2} \mathrm{O} \mathrm{m}^{-2}$ ) & $\begin{array}{l}63.00 \\
\pm \\
38.40\end{array}$ & $\begin{array}{l}30.65 \\
\pm 23.50\end{array}$ & $\begin{array}{l}29.90^{*} \\
\pm \\
22.63\end{array}$ & $\begin{array}{l}95.13 \\
\pm 35.33\end{array}$ & $\begin{array}{l}56.08 \\
\pm \\
16.12\end{array}$ & $\begin{array}{l}55.80 \\
\pm \\
31.09\end{array}$ & $\begin{array}{l}100.95 \\
\pm \\
24.11\end{array}$ & $\begin{array}{l}84.53 \\
\pm \\
40.03\end{array}$ & & & $\mathrm{C} x \mathrm{~W} x \mathrm{M}$ \\
\hline Leaf transpiration $\left(\mathrm{mM} \mathrm{H}_{2} \mathrm{O} \mathrm{m}^{-2} \mathrm{~s}^{-1}\right)$ & $\begin{array}{l}1.29 \\
\pm 0.74\end{array}$ & $\begin{array}{l}0.87 \\
\pm 0.28\end{array}$ & $\begin{array}{l}0.62^{*} \\
\pm 0.42\end{array}$ & $\begin{array}{l}1.78 \\
\pm 0.59\end{array}$ & $\begin{array}{l}1.17 \\
\pm 0.31\end{array}$ & $\begin{array}{l}1.10 \\
\pm 0.52\end{array}$ & $\begin{array}{l}1.90 \\
\pm 0.29\end{array}$ & $\begin{array}{l}1.61 \\
\pm 0.64\end{array}$ & & & $\mathrm{C} \times \mathrm{W} \times \mathrm{M}$ \\
\hline
\end{tabular}

Nonmycorrhizal (-M) or mycorrhizal (+M) plants of the improved cultivar Epace-10 or the local variety Carioca from Brazil were either well watered throughout the growth period (WW), or exposed to a drought stress period (DS) with subsequent resupply of water (WR).

Shown are the mean values \pm standard deviations.

Mean values for $-\mathrm{M}$ plants followed by a star are significantly ( $\mathrm{t}$-test; $\mathrm{P}<0.05$ ) different from corresponding values for $+\mathrm{M}$ treatments. The right part of the table shows the results of the Three Way ANOVA. The significant $(\mathrm{P}<0.05)$ influence of the plant genotype $(\mathrm{G})$, the irrigation treatment $(\mathrm{W})$ or mycorrhizal inoculation (M) is indicated by a black dot. Statistical interpretation of the main effect of a factor was not performed in case the size of the factor's effect depended upon the level of another factor (= significant interaction). Significant interactions between factors are indicated in the last column of the table. 
Emir. J. Food Agric. 2009. 21 (2): 01-17

http://cfa.uaeu.ac.ae/ejfa.shtml

Table 2. The total plant dry weight, shoot-root-ratio, leaf loss and water use efficiency of cowpea plants.

\begin{tabular}{|c|c|c|c|c|c|c|c|c|c|c|c|c|c|c|c|}
\hline & \multicolumn{6}{|c|}{ Epace-10 } & \multicolumn{6}{|c|}{ Carioca } & \multirow{2}{*}{\multicolumn{3}{|c|}{$\begin{array}{l}\text { Three Way } \\
\text { ANOVA: }\end{array}$}} \\
\hline & \multicolumn{2}{|c|}{ WW } & \multicolumn{2}{|l|}{ DS } & \multicolumn{2}{|l|}{ WR } & \multicolumn{2}{|c|}{ WW } & \multicolumn{2}{|l|}{ DS } & \multicolumn{2}{|l|}{ WR } & & & \\
\hline & $-\mathbf{M}$ & $+\mathbf{M}$ & $-\mathbf{M}$ & $+\mathbf{M}$ & $-\mathbf{M}$ & $+\mathbf{M}$ & $-\mathbf{M}$ & $+\mathbf{M}$ & $-\mathbf{M}$ & $+\mathbf{M}$ & $-\mathbf{M}$ & $+\mathbf{M}$ & G W & $\mathbf{M}$ & I \\
\hline $\begin{array}{l}\text { Total plant DW } \\
\text { (in g per plant) }\end{array}$ & $\begin{array}{l}11.55^{*} \\
\pm 1.27\end{array}$ & $\begin{array}{l}17.79 \\
\pm 2.94\end{array}$ & $\begin{array}{l}9.01 \\
\pm 1.23\end{array}$ & $\begin{array}{l}10.00 \\
\pm 0.20\end{array}$ & $\begin{array}{l}8.38 * \\
\pm 1.22\end{array}$ & $\begin{array}{l}14.56 \\
\pm 1.63\end{array}$ & $\begin{array}{l}18.32 * \\
\pm 1.59\end{array}$ & $\begin{array}{l}22.00 \\
\pm 1.13\end{array}$ & $\begin{array}{l}10.26 \\
\pm 0.75\end{array}$ & $\begin{array}{l}10.57 \\
\pm 0.43\end{array}$ & $\begin{array}{l}13.94 * \\
\pm 1.04\end{array}$ & $\begin{array}{l}17.15 \\
\pm 1.50\end{array}$ & $\bullet \bullet$ & $\bullet$ & \\
\hline $\begin{array}{l}\text { Shoot / Root - } \\
\text { ratio }\end{array}$ & $\begin{array}{l}3.65^{*} \\
\pm 0.82\end{array}$ & $\begin{array}{l}2.36 \\
\pm 0.24\end{array}$ & $\begin{array}{l}3.23 \\
\pm 0.25\end{array}$ & $\begin{array}{l}3.66 \\
\pm 1.10\end{array}$ & $\begin{array}{l}3.95 \\
\pm 0.61\end{array}$ & $\begin{array}{l}3.19 \\
\pm 0.41\end{array}$ & $\begin{array}{l}2.28 \\
\pm 0.61\end{array}$ & $\begin{array}{l}2.19 \\
\pm 0.42\end{array}$ & $\begin{array}{l}1.77^{*} \\
\pm 0.19\end{array}$ & $\begin{array}{l}2.03 \\
\pm 0.22\end{array}$ & $\begin{array}{l}2.02 \\
\pm 0.18\end{array}$ & $\begin{array}{l}1.55 \\
\pm 0.17\end{array}$ & & & $\begin{array}{l}\mathrm{C} \\
x \\
\mathrm{~W}\end{array}$ \\
\hline $\begin{array}{l}\text { DW of lost } \\
\text { leaves } \\
\text { (\% of total plant } \\
\text { DW) }\end{array}$ & $\begin{array}{l}19.49 \\
\pm 13.15\end{array}$ & $\begin{array}{l}12.07 \\
\pm 2.33\end{array}$ & $\begin{array}{l}1.72 \\
\pm 1.39\end{array}$ & $\begin{array}{l}1.65 \\
\pm 2.54\end{array}$ & $\begin{array}{l}28.76^{*} \\
\pm 5.31\end{array}$ & $\begin{array}{l}8.06 \\
\pm 6.04\end{array}$ & $\begin{array}{l}14.20^{*} \\
\pm 3.55\end{array}$ & $\begin{array}{l}3.81 \\
\pm 3.59\end{array}$ & $\begin{array}{l}11.82 \\
\pm 5.30\end{array}$ & $\begin{array}{l}5.66 \\
\pm 2.39\end{array}$ & $\begin{array}{l}20.59^{*} \\
\pm 6.25\end{array}$ & $\begin{array}{l}10.57 \\
\pm 3.87\end{array}$ & $\bullet$ & $\bullet$ & \\
\hline $\begin{array}{l}\text { Water use } \\
\text { efficiency } \\
\left(\mathrm{g} \mathrm{DW} \mathrm{L}^{-1} \mathrm{H}_{2} \mathrm{O}\right)\end{array}$ & $\begin{array}{l}4.33 \\
\pm 0.23\end{array}$ & $\begin{array}{l}4.91 \\
\pm 0.81\end{array}$ & $\begin{array}{l}4.96 \\
\pm 0.45\end{array}$ & $\begin{array}{l}5.25 \\
\pm 0.83\end{array}$ & $\begin{array}{l}4.00^{*} \\
\pm 0.14\end{array}$ & $\begin{array}{l}4.94 \\
\pm 0.62\end{array}$ & $\begin{array}{l}4.84 \\
\pm 0.19\end{array}$ & $\begin{array}{l}5.01 \\
\pm 0.23\end{array}$ & $\begin{array}{l}4.87^{*} \\
\pm 0.27\end{array}$ & $\begin{array}{l}4.41 \\
\pm 0.22\end{array}$ & $\begin{array}{l}4.62 \\
\pm 0.49\end{array}$ & $\begin{array}{l}4.39 \\
\pm 0.49\end{array}$ & & & $\begin{array}{l}\mathrm{C} \\
x \\
\mathrm{M} \\
\end{array}$ \\
\hline
\end{tabular}

For statistics and treatment abbreviations see Table $1 ;{ }^{\text {a }}$ leaves lost over the growth period were included into the estimation of these values 
Compared with standard values cited by Bergmann (1992), concentrations of $P$ in the shoot tissue of $-\mathrm{M}$ plants were generally indicative of severe deficiency, while the $\mathrm{P}$ status of $+\mathrm{M}$ plants was in a sufficient range. Levels of $\mathrm{N}$ and $\mathrm{K}$ were also in a low but probably not yet growth limiting range, while supply with $\mathrm{Zn}$ and $\mathrm{Cu}$ was sufficient.

Despite a higher $\mathrm{P}$ and $\mathrm{N}$ nutritional status, $+\mathrm{M}$ plants did not show an increased net photosynthesis compared with -M controls under dry soil conditions, and the WUE of DS plants in our study was either unaffected or slightly decreased by AM fungal inoculation. This suggests that under drought, performance of $+\mathrm{M}$ and $-\mathrm{M}$ plants was similarly limited by water availability. These findings cannot confirm earlier studies where an improved internal WUE, maintenance of higher rates of leaf elongation or higher rates of net photosynthesis were reported for AM compared with non-AM plants under conditions of drought (Osonubi, 1994; Duan et al., 1996; Aroca et al., 2008).

Though the cowpea plants in our study did not benefit from AM inoculation in terms of better plant growth under drought conditions, $+\mathrm{M}$ treatments of both genotypes recovered much faster after water resupply compared with $-\mathrm{M}$ plants. With a diameter of only 2 to $15 \mu \mathrm{m}$, AM fungal hyphae have access to small soil pores which remain filled with soil solution even under low soil moisture regimes (Faber et al., 1991). This may better enable them to take up not only water, but also nutrients from dry soil compared with plant roots. A high contribution of AM fungi to plant uptake of $\mathrm{P}$ and $\mathrm{N}$ under dry soil conditions has been reported previously (Subramanian and Charest, 1999; Neumann and George, 2004). Higher concentrations of $P$ and $N$ in the tissue of $+\mathrm{M}$ compared with $-\mathrm{M}$ plants harvested by the end of the drought stress period suggest that AM fungi might have contributed to the uptake of nutritional elements from dry soil in our experiment. However, the plants were able to use this additional supply of nutrients for better growth only after water availability was no longer limiting photosynthesis and tissue expansion. A faster recovery of $+\mathrm{M}$ compared with $-\mathrm{M}$ plants after water resupply was apparently mainly due to an improved nutritional status of $+\mathrm{M}$ plants. Much lower daily evapotranspiration observed in -M compared with $+\mathrm{M}$ treatments after water resupply were probably the result of higher leaf loss and lower growth rates in $-\mathrm{M}$ plants suffering severe $\mathrm{P}$ deficiency.

As obligate biotrophs, AM fungi depend on the supply with plant carbohydrates for survival (Bago and Bécard, 2002). When plant photosynthesis is limited by drought, amounts of carbohydrates transferred to the AM symbiosis may decrease. However, negative as well as neutral or positive effects of drought stress on intraand extraradical development of the AM symbiosis have been reported (Fagbola et al., 2001; Staddon et al., 2003; Khalvati et al., 2005). During the three weeks of water resupply, +M WR plants almost doubled their $\mathrm{P}$ content compared with the $+\mathrm{M}$ plants harvested by the end of the drought stress period. Only a much smaller increase in $\mathrm{P}$ content could be observed in the corresponding -M treatments. This may suggest that the AM hyphae well survived the drought stress period and became particularly active in nutrient uptake immediately after water resupply. The results of the estimation of the AM fungal colonized root length also do not point to a negative effect of a low soil moisture regime on AM development in the present study. 
Emir. J. Food Agric. 2009. 21 (2): 01-17

http://cfa.uaeu.ac.ae/ejfa.shtml

Table 3. Plant uptake of mineral elements.

\begin{tabular}{|c|c|c|c|c|c|c|c|c|c|c|c|c|c|c|c|c|}
\hline & \multicolumn{6}{|c|}{ Epace-10 } & \multicolumn{6}{|l|}{ Carioca } & \multirow{2}{*}{\multicolumn{4}{|c|}{$\begin{array}{l}\text { Three Way } \\
\text { ANOVA: }\end{array}$}} \\
\hline & \multicolumn{2}{|c|}{ WW } & \multicolumn{2}{|l|}{ DS } & \multicolumn{2}{|l|}{ WR } & \multicolumn{2}{|l|}{ WW } & \multirow{2}{*}{$\begin{array}{l}\text { DS } \\
-\mathbf{M} \\
\end{array}$} & \multicolumn{3}{|c|}{ WR } & & & & \\
\hline & $-\mathbf{M}$ & $+\mathbf{M}$ & $-\mathbf{M}$ & $+\mathbf{M}$ & $-\mathbf{M}$ & $+\mathbf{M}$ & $-\mathbf{M}$ & $+\mathbf{M}$ & & $+\mathbf{M}$ & $-\mathbf{M}$ & $+\mathbf{M}$ & G & $\mathbf{W}$ & M I & I \\
\hline $\begin{array}{l}\text { Total plant } \mathrm{P} \\
\text { uptake }^{\mathrm{a}} \\
\text { (mg per } \\
\text { plant) }\end{array}$ & $\begin{array}{l}11.15^{*} \\
\pm 1.05\end{array}$ & $\begin{array}{l}48.16 \\
\pm 4.88\end{array}$ & $\begin{array}{l}8.11 * \\
\pm 1.31\end{array}$ & $\begin{array}{l}22.37 \\
\pm 1.40\end{array}$ & $\begin{array}{l}8.71 * \\
\pm 0.76\end{array}$ & $\begin{array}{l}39.49 \\
\pm 6.05\end{array}$ & $\begin{array}{l}16.27^{*} \\
\pm 1.72\end{array}$ & $\begin{array}{l}51.41 \\
\pm 3.94\end{array}$ & $\begin{array}{l}9.17 * \\
\pm 0.80\end{array}$ & $\begin{array}{l}27.65 \\
\pm 0.95\end{array}$ & $\begin{array}{l}13.85^{*} \\
\pm 0.98\end{array}$ & $\begin{array}{l}46.39 \\
\pm 2.34\end{array}$ & $\bullet$ & $\bullet$ & $\bullet$ & \\
\hline $\begin{array}{l}\text { Total plant K } \\
\text { uptake }^{\mathrm{a}} \\
\text { (mg per } \\
\text { plant) }\end{array}$ & $\begin{array}{l}118.35 * \\
\pm 23.15\end{array}$ & $\begin{array}{l}250.55 \\
\pm 5.24\end{array}$ & $\begin{array}{l}111.37 \\
\pm 8.91\end{array}$ & $\begin{array}{l}129.88 \\
\pm 14.04\end{array}$ & $\begin{array}{l}139.22 \\
* \\
\pm 20.49\end{array}$ & $\begin{array}{l}192.91 \\
\pm 24.53\end{array}$ & $\begin{array}{l}248.65 \\
* \\
\pm 40.96\end{array}$ & $\begin{array}{l}316.18 \\
\pm \\
24.09\end{array}$ & $\begin{array}{l}181.17 \\
* \\
\pm 21.59\end{array}$ & $\begin{array}{l}200.80 \\
\pm 1.93\end{array}$ & $\begin{array}{l}251.53 \\
\pm \\
12.51\end{array}$ & $\begin{array}{l}279.60 \\
\pm \\
25.48\end{array}$ & $\bullet$ & & & $\begin{array}{l}\mathrm{W} x \\
\mathrm{M}\end{array}$ \\
\hline $\begin{array}{l}\text { Total plant } N \\
\text { uptake }^{\mathrm{a}} \\
\text { (mg per } \\
\text { plant) }\end{array}$ & $\begin{array}{l}250.14^{*} \\
\pm 21.34\end{array}$ & $\begin{array}{l}306.02 \\
\pm \\
25.87\end{array}$ & $\begin{array}{l}167.55 \\
* \\
\pm 22.90\end{array}$ & $\begin{array}{l}221.15 \\
\pm 5.54\end{array}$ & $\begin{array}{l}179.80 \\
* \\
\pm 11.95\end{array}$ & $\begin{array}{l}289.37 \\
\pm 19.62\end{array}$ & $\begin{array}{l}280.44 \\
\pm 77.41\end{array}$ & $\begin{array}{l}330.45 \\
\pm \\
12.88\end{array}$ & $\begin{array}{l}203.08 \\
\pm 15.88\end{array}$ & $\begin{array}{l}220.57 \\
\pm \\
12.53\end{array}$ & $\begin{array}{l}334.67 \\
\pm \\
27.33\end{array}$ & $\begin{array}{l}314.29 \\
\pm \\
17.84\end{array}$ & & & & $\begin{array}{l}\mathrm{C} \times \mathrm{W} \\
\mathrm{C} \times \mathrm{M} \\
\mathrm{C} \times \mathrm{W} \\
x \mathrm{M}\end{array}$ \\
\hline $\begin{array}{l}\text { Total plant } \\
\text { Zn uptake } \\
\text { (mg per } \\
\text { plant) }\end{array}$ & $\begin{array}{l}1.21 * \\
\pm 0.05\end{array}$ & $\begin{array}{l}2.23 \\
\pm 0.41\end{array}$ & $\begin{array}{l}0.84 * \\
\pm 0.13\end{array}$ & $\begin{array}{l}1.06 \\
\pm 0.09\end{array}$ & $\begin{array}{l}0.94 * \\
\pm 0.13\end{array}$ & $\begin{array}{l}1.68 \\
\pm 0.31\end{array}$ & $\begin{array}{l}1.81 * \\
\pm 0.32\end{array}$ & $\begin{array}{l}2.78 \\
\pm 0.36\end{array}$ & $\begin{array}{l}1.00 * \\
\pm 0.07\end{array}$ & $\begin{array}{l}1.25 \\
\pm 0.10\end{array}$ & $\begin{array}{l}1.58 \\
\pm 0.30\end{array}$ & $\begin{array}{l}2.49 \\
\pm 0.52\end{array}$ & $\bullet$ & $\bullet$ & $\bullet$ & \\
\hline $\begin{array}{l}\text { Total plant } \\
\text { Cu uptake } \\
\text { (mg per } \\
\text { plant) }\end{array}$ & $\begin{array}{l}0.34 * \\
\pm 0.05\end{array}$ & $\begin{array}{l}0.58 \\
\pm 0.08\end{array}$ & $\begin{array}{l}0.23 \\
\pm 0.05\end{array}$ & $\begin{array}{l}0.25 \\
\pm 0.03\end{array}$ & $\begin{array}{l}0.27 * \\
\pm 0.03\end{array}$ & $\begin{array}{l}0.42 \\
\pm 0.08\end{array}$ & $\begin{array}{l}0.32^{*} \\
\pm 0.03\end{array}$ & $\begin{array}{l}0.63 \\
\pm 0.08\end{array}$ & $\begin{array}{l}0.15 * \\
\pm 0.02\end{array}$ & $\begin{array}{l}0.27 \\
\pm 0.02\end{array}$ & $\begin{array}{l}0.29 * \\
\pm 0.03\end{array}$ & $\begin{array}{l}0.57 \\
\pm 0.03\end{array}$ & & $\bullet$ & & $\mathrm{C} \times \mathrm{M}$ \\
\hline
\end{tabular}

${ }^{a}$ leaves lost over the growth period were included into the estimation of these values

For treatment abbreviations and statistics see Table 1 
Table 4. Element concentrations in the shoot tissue of cowpea plants.

\begin{tabular}{|c|c|c|c|c|c|c|c|c|c|c|c|c|c|c|c|c|}
\hline & \multicolumn{6}{|c|}{ Epace-10 } & \multicolumn{6}{|l|}{ Carioca } & \multirow{2}{*}{\multicolumn{4}{|c|}{$\begin{array}{l}\text { Three Way } \\
\text { ANOVA: }\end{array}$}} \\
\hline & \multicolumn{2}{|c|}{ WW } & \multicolumn{2}{|l|}{ DS } & \multicolumn{2}{|l|}{ WR } & \multicolumn{2}{|l|}{ WW } & \multicolumn{2}{|l|}{ DS } & \multicolumn{2}{|l|}{ WR } & & & & \\
\hline & $-\mathbf{M}$ & $+\mathbf{M}$ & $-\mathbf{M}$ & $+\mathbf{M}$ & $-\mathbf{M}$ & $+\mathbf{M}$ & $-\mathbf{M}$ & $+\mathbf{M}$ & $-\mathbf{M}$ & $+\mathbf{M}$ & $-\mathbf{M}$ & $+\mathbf{M}$ & $\mathbf{G}$ & $\mathbf{W}$ & $\mathbf{M}$ & I \\
\hline $\begin{array}{l}\text { Shoot P } \\
\text { (in mg } \\
\mathrm{g} \mathrm{DW}^{-1} \text { ) }\end{array}$ & $\begin{array}{l}0.87^{*} \\
\pm 0.06\end{array}$ & $\begin{array}{l}2.51 \\
\pm 0.22\end{array}$ & $\begin{array}{l}0.83 * \\
\pm 0.10\end{array}$ & $\begin{array}{l}2.09 \\
\pm 0.19\end{array}$ & $\begin{array}{l}0.99 * \\
\pm 0.07\end{array}$ & $\begin{array}{l}2.62 \\
\pm 0.22\end{array}$ & $\begin{array}{l}0.79 * \\
\pm 0.06\end{array}$ & $\begin{array}{l}2.16 \\
\pm 0.12\end{array}$ & $\begin{array}{l}0.66 * \\
\pm 0.12\end{array}$ & $\begin{array}{l}2.44 \\
\pm 0.14\end{array}$ & $\begin{array}{l}0.94 * \\
\pm 0.14\end{array}$ & $\begin{array}{l}2.45 \\
\pm 0.19\end{array}$ & $\bullet$ & - & $\bullet$ & \\
\hline $\begin{array}{l}\text { Shoot K } \\
\text { (in mg } \\
\mathrm{g} \mathrm{DW}^{-1} \text { ) }\end{array}$ & $\begin{array}{l}12.80 \\
\pm 2.34\end{array}$ & $\begin{array}{l}12.47 \\
\pm 3.06\end{array}$ & $\begin{array}{l}10.05 \\
\pm 3.13\end{array}$ & $\begin{array}{l}11.51 \\
\pm 2.31\end{array}$ & $\begin{array}{l}17.46 * \\
\pm 0.58\end{array}$ & $\begin{array}{l}11.57 \\
\pm 3.77\end{array}$ & $\begin{array}{l}11.34 * \\
\pm 0.25\end{array}$ & $\begin{array}{l}12.74 \\
\pm 0.53\end{array}$ & $\begin{array}{l}17.14 \\
\pm 2.33\end{array}$ & $\begin{array}{l}20.06 \\
\pm 1.12\end{array}$ & $\begin{array}{l}16.63 \\
\pm 2.58\end{array}$ & $\begin{array}{l}15.83 \\
\pm 2.10\end{array}$ & & & & $\begin{array}{l}\mathrm{C} \times \mathrm{M} \\
\mathrm{W} \times \mathrm{M}\end{array}$ \\
\hline $\begin{array}{l}\text { Shoot N } \\
\text { (in } \mathrm{mg} \\
\mathrm{g} \mathrm{DW}^{-1} \text { ) }\end{array}$ & $\begin{array}{l}18.31 \\
\pm 5.51\end{array}$ & $\begin{array}{l}17.33 \\
\pm 1.87\end{array}$ & $\begin{array}{l}17.04 * \\
\pm 1.18\end{array}$ & $\begin{array}{l}21.17 \\
\pm 0.27\end{array}$ & $\begin{array}{l}21.35 \\
\pm 2.70\end{array}$ & $\begin{array}{l}20.13 \\
\pm 2.69\end{array}$ & $\begin{array}{l}14.28 \\
\pm 4.54\end{array}$ & $\begin{array}{l}13.38 \\
\pm 0.11\end{array}$ & $\begin{array}{l}17.57 \\
\pm 0.63\end{array}$ & $\begin{array}{l}18.96 \\
\pm 1.44\end{array}$ & $\begin{array}{l}25.02 * \\
\pm 2.94\end{array}$ & $\begin{array}{l}16.80 \\
\pm 0.50\end{array}$ & & & $\bullet$ & \\
\hline $\begin{array}{l}\text { Shoot } \mathrm{Zn} \\
(\text { in } \mu \mathrm{g} \\
\mathrm{g} \mathrm{DW}^{-1} \text { ) }\end{array}$ & $\begin{array}{l}83.46^{*} \\
\pm 4.50\end{array}$ & $\begin{array}{l}111.50 \\
\pm \\
13.25\end{array}$ & $\begin{array}{l}81.05 \\
\pm 11.44\end{array}$ & $\begin{array}{l}83.71 \\
\pm 4.98\end{array}$ & $\begin{array}{l}90.66 \\
\pm 8.38\end{array}$ & $\begin{array}{l}98.03 \\
\pm 9.90\end{array}$ & $\begin{array}{l}78.29 * \\
\pm 11.65\end{array}$ & $\begin{array}{l}108.29 \\
\pm \\
11.21\end{array}$ & $\begin{array}{l}81.36 \\
\pm 4.85\end{array}$ & $\begin{array}{l}101.28 \\
\pm \\
19.36\end{array}$ & $\begin{array}{l}93.83 \\
\pm \\
17.39\end{array}$ & $\begin{array}{l}116.23 \\
\pm \\
10.44\end{array}$ & & & $\bullet$ & \\
\hline $\begin{array}{l}\text { Shoot Cu } \\
\text { (in } \mu \mathrm{g} \\
\mathrm{g} \mathrm{DW}^{-1} \text { ) }\end{array}$ & $\begin{array}{l}9.45 \\
\pm 2.42\end{array}$ & $\begin{array}{l}10.87 \\
\pm 0.53\end{array}$ & $\begin{array}{l}15.69 * \\
\pm 3.83\end{array}$ & $\begin{array}{l}9.09 \\
\pm 0.66\end{array}$ & $\begin{array}{l}14.06^{*} \\
\pm 0.65\end{array}$ & $\begin{array}{l}10.70 \\
\pm 1.51\end{array}$ & $\begin{array}{l}5.41 \\
\pm 1.29\end{array}$ & $\begin{array}{l}6.98 \\
\pm 0.89\end{array}$ & $\begin{array}{l}5.97 \\
\pm 0.31\end{array}$ & $\begin{array}{l}6.36 \\
\pm 0.57\end{array}$ & $\begin{array}{l}7.33 \\
\pm 0.89\end{array}$ & $\begin{array}{l}8.66 \\
\pm 1.81\end{array}$ & & & & $\begin{array}{l}\mathrm{C} \times \mathrm{M} \\
\mathrm{W} \times \mathrm{M} \\
\mathrm{C} \times \mathrm{W} \\
x \mathrm{M}\end{array}$ \\
\hline
\end{tabular}


In our experiment where plants grew in a soil with a low availability of $\mathrm{P}, \mathrm{K}$ and $\mathrm{N}$, the local cowpea variety Carioca achieved higher DW and acquired larger amounts of mineral nutrients from the soil compared with Epace-10 in all irrigation treatments. Our results thus do not support earlier findings where a better growth and nutrient uptake of breeding improved plant genotypes under limited supply of nutrients was reported. The performance of Epace-10 was particularly poor when plants of this cultivar were -M. Differences in growth and nutrient uptake between $+\mathrm{M}$ and $-\mathrm{M}$ plants were smaller for Carioca compared with Epace-10. These findings point to a higher dependency of Epace-10 compared with Carioca on the AM symbiosis for growth and nutrient uptake under conditions of drought and/or low nutrient availability. The lower shoot/root-ratio of Carioca may indicate that these plants had a higher nutrient absorptive root surface. It has been shown previously that plant dependency on the AM symbiosis for nutrient uptake increases with decreasing root surface (Schweiger et al., 1995; Khalil et al., 1999).

\section{Conclusion}

Our results suggest that plants benefit from the AM symbiosis under dry soil conditions mainly in terms of an improved nutrient uptake. This may greatly facilitate the recovery of plants when water is resupplied. Our results further demonstrate that the breeding improved cowpea cultivar Epace-10 is strongly dependent on the association with AM fungi for growth and nutrient uptake on a dry soil with a low nutrient availability. Plants of this cultivar were only able to recover from a period of drought when AM colonized. Mycotrophic plants may greatly benefit from root colonization by AM fungi in terms of growth and nutrient uptake when exposed to temporarily limited periods of drought. It is recommended to monitor AM root colonization of such plants in the field, and to inoculate the soil with drought tolerant AM fungal strains in case the naturally occurring AM infective potential should be too low to initiate appropriate symbiosis development.

\section{References}

Abeledo, G. L., D. F. Calderini and G. A. Slafer. 2003. Genetic improvement of yield responsiveness to nitrogen fertilization and its physiological determinants in barley. Euphytica 133:291-298.

Al-Karaki, G. N. and R. B. Clark. 1998. Growth, mineral acquisition, and water use by mycorrhizal wheat grown under water stress. J. Plant Nutr. 21:263-276.

Aroca, R., P. Vernieri and J. M. RuizLozano. 2008. Mycorrhizal and nonmycorrhizal Lactuca sativa plants exhibit contrasting responses to exogenous ABA during drought stress and recovery. J. Exp. Bot. 59:2029-2041.

Auble, D. L. and T. P. Meyers. 1992. An open path, fast response infrared absorption gas analyzer for $\mathrm{H}_{2} \mathrm{O}$ and $\mathrm{CO}_{2}$. Bound.-Lay. Meteorol. 59:243256.

Augé, R. M. 2001. Water relations, drought and vesicular-arbuscular mycorrhizal symbiosis. Mycorrhiza 11:3-42.

Augé, R. M. 2004. Arbuscular mycorrhizae and soil/plant water relations. Can. J. Soil. Sci. 84:373381.

Augé, R. M., H. D. Toler, J. L. Moore, K. Cho and A. M. Saxton. 2007. Comparing contributions of soil versus root colonization to 
variations in stomatal behaviour and soil drying in mycorrhizal Sorghum bicolor and Cucurbita pepo. J. Plant Physiol. 164:1289-1299.

Bago, B. and G. Bécard. 2002. Bases of the obligate biotrophy of arbuscular mycorrhizal fungi. In: S. Gianinazzi, H. Schüepp, J. M. Barea and K. Haselwandter (Eds). pp. 235-247. Mycorrhizal Technology in Agriculture. Birkhäuser Verlag. Switzerland.

Bergmann, W. 1992. Nutritional Disorders of Cultivated Plants Development, Visual and Analytical Diagnosis. Gustav Fischer Verlag. Germany.

Brachmann, A. and M. Parniske. 2006. The most important symbiosis on earth. PLoS Biol. 4:239.

Bray, E. A. 1997. Plant responses to water deficit. Trends Plant Sci. 2: 48-54.

Chaudhry, M. S., Z. Batool and A. G. Khan. 2005. Preliminary assessment of plant community structure and arbuscular mycorrhizas in rangeland habitats of Cholistan desert, Pakistan. Mycorrhiza 15:606-611.

Davies, W., S. Wilkinson and B. Loveys. 2002. Stomatal control by chemical signalling and the exploitation of this mechanism to increase water use efficiency in agriculture. New Phytol. 153:449-460.

Duan, X., D. S. Neumann, J. M. Reiber, C. D. Green, A. M. Saxton and R. M. Augé. 1996. Mycorrhizal influence on hydraulic and hormonal factors implicated in the control of stomatal conductance during drought. J. Exp. Bot. 47:1541-1550.
Eason, W. R., K. J. Webb, T. P. T. Michaelson-Yeates, M. T. Abberton, G. W. Griffith, C. M. Culshaw, J. E. Hooker and M. S. Dhanoa. 2001. Effect of genotype of Trifolium repens on mycorrhizal symbiosis with Glomus mosseae. J. Agr. Sci. 137:27-36.

Faber, B. A., R. J. Zasoski, D. N. Munns and K. Shackel. 1991. A method for measuring hyphal nutrient and water uptake in mycorrhizal plants. Can. J. Bot. 69:87-94.

Fagbola, O., O. Osonubi, K. Mulongoy and S. A. Odufna. 2001. Effects of drought stress and arbuscular mycorrhiza on the growth of Gliricidia sepium (Jacq.) Walp. and Leucaena leucocephala (Lam.) de Wit in simulated eroded soil conditions. Mycorrhiza 11:215-223.

Gahoonia, T. S., S. Raza and N. E. Nielsen. 1994. Phosphorus depletion in the rhizosphere as influenced by soil moisture. Plant Soil 159:213218 .

George, E. 2000. Contribution of arbuscular mycorrhizal fungi to plant mineral nutrition. In: Y. Kapulnik and D. D. Douds Jr. (Eds). pp. 307-343. Arbuscular Mycorrhizas: Physiology and Function. Kluwer Academic Publishers. Netherlands.

George, E., K.-U. Häussler, D. Vetterlein, E. Gorgus and H. Marschner. 1992. Water and nutrient translocation by hyphae of Glomus mosseae. Can. J. Bot. 70:2130-2137.

Gericke, S. and B. Kurmies. 1952. Die colorimetrische Phosphorsäure bestimmung mit AmmoniumVanadat-Molybdat und ihre 
Anwendung in der Pflanzenanalyse. Z. Pflanz. Bodenkunde 159:11-21.

Graham, J. H., L. W. Duncan and D. M. Eissenstat. 1997. Carbohydrate allocation patterns in citrus genotypes as affected by phosphorus nutrition, mycorrhizal colonisation and mycorrhizal dependency. New Phytol. 135:335-343.

Guarda, G., S. Padovan and G. Delogu. 2004. Grain yield, nitrogen-use efficiency and baking quality of old and modern Italian bread-wheat cultivars grown at different nitrogen levels. Europ. J. Agron. 21:181-192.

Hetrick, B. A. D., G. W. T. Wilson and T. S. Cox. 1992. Mycorrhizal dependence of modern wheat varieties, landraces, and ancestors. Can. J. Bot. 70:2032-2040.

Kabas, O., E. Yilmaz, A. Ozmerzi and I. Akinci. 2007. Some physical and nutritional properties of cowpea seed (Vigna sinensis L.). J. Food Eng. 79:1405-1409.

Khalil, S., T. E. Loynachan and M. A. Tabatabi. 1999. Plant determinants of mycorrhizal dependency in soybean. Agron. J. 91:135-141.

Khalvati, M. A., Y. Hu, A. Mozafar and U. Schmidthalter. 2005. Quantification of water uptake by Arbuscular mycorrhizal hyphae and its significance for leaf growth, water relations, and gas exchange of barley subjected to drought stress. Plant Biol. 7:706-712.

Koide, R. 1993. Physiology of the mycorrhizal plant. Advanced Plant Pathol. 9:33-54.

Kolawole, G. O., G. L. Tiang and B. B. Singh. 2000. Differential response of cowpea lines to aluminium and phosphorus application. J. Plant Nutr. 23:731-740.

Kormanik, P. and A. C. McGraw. 1982. Quantification of vesiculararbuscular mycorrhizae in plant roots. In: N. C. Schenck (Ed). pp. 37-45. Methods and Principals of Mycorrhizal Research. The American Phytopathological Society. USA.

Koske, R. E. and J. N. Gemma. 1989. A modified procedure for staining roots to detect VA mycorrhizas. Mycol. Res. 92:486-505.

Labuschagne, M. T., R. Verhoeven and M. Nkouanessi. 2008. Drought tolerance assessment of African cowpea accessions based on stomatal behaviour and cell membrane stability. J. Agr. Sci. 146:689-694.

Linderman, R. G. and E. A. Davis. 2004. Varied response of marigold (Tagetes spp.) genotypes to inoculation with different arbuscular mycorrhizal fungi. Sci. Hortic. Amsterdam 99:6778.

Marulanda, A., R. Azcón and J. M. RuízLozano. 2003. Contribution of six arbuscular mycorrhizal fungal isolates to water uptake by Lactuca sativa under drought stress. Physiol. Plant. 119:526-533.

Marulanda, A., R. Porcel, J. M. Barea and R. Azcón. 2007. Drought tolerance and antioxidant activities in lavender plants colonized by native drought-tolerant or droughtsensitive Glomus species. Microb. Ecol. 54:543-552.

Neumann, E. and E. George. 2004. Colonization with the arbuscular 
mycorrhizal fungus Glomus mosseae (Nicol. \& Gerd.) enhanced phosphorus uptake from dry soil in Sorghum bicolor (L.). Plant Soil 261:245-255.

Neumann, E., B. Schmid, V. Römheld and E. George. 2009. Extraradical development and contribution to plant performance of an arbuscular mycorrhizal symbiosis exposed to complete or partial rootzone drying. Mycorrhiza 20:13-23.

Okon, I. E., O. Osonubi, and N. Sanginga. 1996. Vesicular-arbuscular mycorrhiza effects on Fliricidia sepium and Senna siamea in a fallowed alley cropping system. Agrofor. Syst. 33:165-175.

Osonubi, O. 1994. Comparative effects of vesicular arbuscular mycorrhizal inoculation and phosphorus fertilization on growth and phosphorus uptake of maize (Zea mays L.) and sorghum (Sorghum bicolor L.) plants under drought-stressed conditions. Biol. Fert. Soils 18:55-59.

Passioura, J. 2007. The drought environment: physical, biological and agricultural perspectives. J. Exp. Bot. 58:113-117.

Pinior, A., G. Grunewaldt-Stöcker, H. von Alten and R. J. Strasser. 2005. Mycorrhizal impact on droght stress tolerance of rose plants probed by chlorophyll $a$ fluorescence, proline content and visual scoring. Mycorrhiza 15:596-605.

Porcel, R., and J. M. Ruiz-Lozano. 2004. Arbuscular mycorrhizal influence on leaf water potential, solute accumulation, and oxidative stress in soybean plants subjected to drought stress. J. Exp. Bot. 55:1743-1750.
Roth, K., R. Schulin, H. Flühler and W. Attinger. 1990. Calibration of time domain reflectometry for water content measurement using a composite dielectric approach. Water Resour. Res. 26:2267-2273.

Ruiz-Lozano, J. M., R. Azcòn and M. Gomez. 1995. Effects of arbuscular mycorrhizal Glomus species on drought tolerance: Physiological and nutritional plant responses. Appl. Environ. Microbiol. 61:456-460.

Schellenbaum, L., J. Müller, T. Boller, A. Wiemken and H. Schüepp. 1998. Effects of drought on nonmycorrhizal and mycorrhizal maize: changes in the pools of nonstructural carbohydrates, in the activities of invertase and trehalase, and in the pools of amino acids and imino acids. New Phytol. 138:59-66.

Schüller, H. 1969. Die CAL-Methode, eine neue Methode zur Bestimmung des pflanzenverfügbaren Phosphates im Boden. Z. Pflanz. Bodenkunde 123:48-63.

Schweiger, P. F., A. D. Robson and N. J. Barrow. 1995. Root hair length determines beneficial effect of a Glomus species on shoot growth of some pasture species. New Phytol. 131:247-254.

Shi, Z. Y., G. Feng, P. Christie and X. L. Li. 2006. Arbuscular mycorrhizal status of spring ephemerals in the desert ecosystem of Junggar Basin, China. Mycorrhiza 16:269-275.

Silva-Barbeau, I., H. Sissoko, M. Berthe, M. Haidara, W. E. Barbeau and J. S. Caldwell. 1998. Addressing child feeding concerns of women farmers in Mali: Composition and effects on child nutrition of locally developed 
weaning food. Ecol. Food Nutr. 37:119.

Smith, S. E. and D. J. Read. 2008. Mycorrhizal Symbioses. $3^{\text {rd }}$ ed. Academic Press. UK.

Staddon, P. L., C. B. Ramsey, N. Ostle, P. Ineson and A. H. Fitter. 2003. Rapid turnover of hyphae of mycorrhizal fungi determined by AMS microanalysis of ${ }^{14} \mathrm{C}$. Science 300:1138-1140.

Subramanian, K. S. and C. Charest. 1999. Acquisition of $\mathrm{N}$ by external hyphae of an arbuscular mycorrhizal fungus and its impact on physiological responses in maize under droughtstressed and well-watered conditions. Mycorrhiza 9:69-75.
Tchabi, A., D. Coyne, F. Hountondji, L. Lawouin, A. Wiemken and F. Oehl. 2008. Arbuscular mycorrhizal fungal communities in sub-Saharan Savannas of Benin, West Africa, as affected by agricultural land use intensity and ecological zone. Mycorrhiza 18:181195.

Tennant, D. 1975. A test of a modified line intersect method of estimating root length. J. Ecol. 63:995-1001.

Thieme, P. 1964. Eine gaschromato graphische Bestimmung des Stickstoffund Sauerstoff gehaltes von organischen Verbindungen. Fresen. J. Anal. Chem. 206:50.

Timko, M. P. and B. B. Singh. 2008. Cowpea, a multifunctional legume. In: P. H. Moore and R. Ming (Eds). pp. 227-258. Genomics of Tropical Crop Plants. Springer Verlag. Germany. 